\title{
MODIFICATION OF THE RESPIRATORY RESPONSE TO CARBON DIOXIDE BY SALICYLATE
}

\author{
BY JAMES K. ALEXANDER,1, 2 HAROLD F. SPALTER, 8 AND JOHN R. WEST † \\ (From the Department of Medicine, Columbia University College of Physicians and Surgeons, \\ and the Cardio-pulmonary Laboratory, Presbyterian Hospital, New York, N. Y.)
}

(Submitted for publication July 30, 1954; accepted December 1, 1954)

It is well known that $\mathrm{CO}_{2}$ inhalation is associated with increased ventilation in normal man, and the sensitivity of the nervous regulatory mechanism to this physiological stimulus has been reasonably well defined (1-3). Likewise the clinical entity of hyperventilation associated with salicylate toxicity has long been recognized. The study reported here was designed to investigate one aspect of the effect of salicylate on respiration. Specifically an attempt has been made to determine whether salicylate might induce changes in the sensitivity of the nervous regulatory mechanism to the stimulus of $\mathrm{CO}_{2}$ inhalation.

The approach has been essentially the same as that reported previously (3), namely, the correlation of arterial blood $\mathrm{CO}_{2}$ tension and hydrogen ion concentration with effective alveolar ventilation when changes are induced by increased amounts of $\mathrm{CO}_{2}$ in the inspired air.

\section{MATERIAL AND METHODS}

Three normal medical students were studied in the fasting state. Two studies each were made on two subjects and three on the third, each study extending over the period of one morning. Three sets of observations were made both before and after salicylate ingestion in order to determine three points on each of the stimulus response curves to be constructed. The observations were made while the subjects were breathing room air, 3 per cent $\mathrm{CO}_{2}$ in air, and 5 per cent $\mathrm{CO}_{2}$ in air in that order. The experimental procedure and apparatus used were the same as those previously employed in a larger group of normal subjects (3).

Single doses of 1.8 to 2.4 grams of acetyl salicylic acid were given orally in the form of "Bufferin (2)" tablets

1 Present address: Department of Medicine, Baylor University College of Medicine, Houston, Texas.

2 Supported in part by a gift from the Charles $A$. Frueauff Foundation.

${ }^{8}$ Fourth year student, Columbia University College of Physicians and Surgeons.

† Dr. West died June 29, 1954.

- Acetyl salicylic acid with aluminum glycinate and magnesium carbonate, Bristol Myers Co. approximately one and one-half to two hours before the second study was done, and blood for salicylate levels was drawn at the time the observations on ventilation and arterial blood were made.

In the normal subject a steady state as determined by consistency of respiratory quotient values, pulmonary ventilation, and respiratory frequency is obtained only after 25 to 30 minutes of uninterrupted breathing of a carbon dioxide gas mixture in the concentrations used $(3,4)$. Therefore, expired gas was collected during the last three minutes of 26 to 33-minute periods of continuous inhalation of the two $\mathrm{CO}_{2}$ mixtures. During the middle minute of this three-minute period, arterial blood samples were steadily drawn from an indwelling needle in a brachial artery.

The analytical methods used have been described previously (3). Since the values for arterial $\mathrm{CO}_{2}$ tension were partially derived from the blood $\mathrm{pH}$, and the changes observed were relatively small, special attention was given to the determination of arterial blood $\mathrm{pH}$ in order to insure the greatest possible accuracy permitted by the technique employed. Duplicate determinations were carried out in every instance within five minutes after the blood had been removed from the vessel. Readings were made at $38^{\circ} \mathrm{C}$. using a Cambridge glass electrode $\mathrm{pH}$ meter, transfer from vessel to electrode being accomplished anaerobically. Two standard phosphate buffer solutions of $\mathrm{pH} 7.18$ and 7.58 at $38^{\circ}$ C. (5) were used for reference, and duplicate blood determinations were required to check within $\pm .005 \mathrm{pH}$ units. In this way changes in $\mathrm{pH}$ were measured accurately within $.01 \mathrm{pH}$ unit. Blood salicylate levels were determined colorimetrically (6). The usual 'alveolar' equation was utilized for the calculation of mean alveolar oxygen tension (7) when room air was inhaled, and in modified form (3) when $\mathrm{CO}_{2}$ was added to the inspired air. Calculated values for whole blood buffer base were obtained from the Singer-Hastings nomogram (8).

If it can be assumed that in a steady state a consistent relationship or equilibrium exists between the concentration of certain chemical agents in the arterial blood and their intra-and/or extracellular concentrations acting at receptor or integrative levels on the nervous mechanism regulating respiration, then simultaneous measurement of arterial concentrations and pulmonary ventilation under varying conditions will permit the estimation of a stimulus response curve.

In analyzing the results of the study, the assumed physiological stimuli to respiration, i.e., $\mathrm{CO}_{2}$ tension and 
hydrogen ion concentration in the arterial blood, have been plotted against effective alveolar ventilation. Effective alveolar ventilation has been taken as the total pulmonary ventilation minus the physiological dead space ventilation (Bohr) to $\mathrm{CO}_{2}$, assuming the arterial $\mathrm{CO}_{2}$ tension to be equivalent to the mean alveolar tension. Alveolar ventilation has been utilized in constructing the stimulus response curves rather than the total pulmonary ventilation since it is the former which determines the tension of $\mathrm{CO}_{2}$ in the arterial blood perfusing the receptor sites of the neural regulatory mechanism.

\section{RESULTS}

As indicated by the consistency of the respiratory exchange ratios, ${ }^{5}$ a reasonably steady state was achieved in all three subjects during $\mathrm{CO}_{2}$ inhalation in the control periods and following salicylate ingestion (Table I). In addition, relatively constant levels of salicylate ranging from

- Respiratory exchange ratio of expired air is used here as synonymous with respiratory quotient.
12 to $16 \mathrm{mg}$. per cent were obtained in the blood throughout the entire period of study in each subject (Table I). The latter findings were essentially the same as those of Smith, Gleason, Stoll, and Ogorzalek (6), who observed that after single 2 gram oral doses of acetyl salicylate the maximum plasma salicylate level was reached about one and one-half to two hours after ingestion and remained relatively constant for six hours thereafter.

The control observations (Tables I, II) on the ventilatory response to the increases in arterial $\mathrm{CO}_{2}$ tension and hydrogen ion concentration associated with $\mathrm{CO}_{2}$ inhalation were comparable to those made on a larger number of normal subjects. For a detailed discussion of the changes in pulmonary ventilation and arterial blood in normal subjects under these circumstances, the reader is referred to a previous report (3).

TABLE I

Physiologic data relative to pulmonary ventilation at rest and following salicylate ingestion *

\begin{tabular}{|c|c|c|c|c|c|c|c|c|c|c|c|c|c|c|c|}
\hline Subject & State & Age & Sex & B.S.A. $†$ & $\begin{array}{l}\text { Dose, } \\
\text { ASAf }\end{array}$ & $\begin{array}{c}\text { Blood } \\
\text { salicylate } \\
\text { level }\end{array}$ & $\begin{array}{l}\text { Inspired } \\
\text { mixture }\end{array}$ & $\begin{array}{l}\text { Minutes } \\
\text { on } \\
\text { mixture }\end{array}$ & f & $\mathbf{R E}$ & $\mathbf{V}_{\mathbf{T}}$ & VD\& & $V_{x}$ & $\mathbf{V}_{\mathbf{A}}$ & $\mathbf{P}_{\mathbf{A}_{\mathbf{O}_{2}}}$ \\
\hline \multirow[t]{2}{*}{ B. C. } & Rest & 23 & $\mathbf{M}$ & 2.06 & srams & mg. \% & $\begin{array}{l}\text { Rm. air } \\
3 \% \mathrm{CO}_{2} \\
5 \% \mathrm{CO}_{2}\end{array}$ & $\begin{array}{l}\overline{27} \\
30\end{array}$ & $\begin{array}{l}13 \\
15.3 \\
26\end{array}$ & $\begin{array}{l}0.75 \\
0.85 \\
0.85\end{array}$ & $\begin{array}{r}528 \\
738 \\
1,075\end{array}$ & $\begin{array}{l}200 \\
257 \\
564\end{array}$ & $\begin{array}{r}6.87 \\
11.32 \\
27.95\end{array}$ & $\begin{array}{r}4.27 \\
7.38 \\
13.28\end{array}$ & $\begin{array}{r}95 \\
121 \\
130\end{array}$ \\
\hline & $\begin{array}{l}\text { Post } \\
\text { ASA }\end{array}$ & & & & 2.4 & $\begin{array}{l}14.9 \\
16.4 \\
16.4\end{array}$ & $\begin{array}{l}\mathrm{Rm} . \text { air } \\
3 \% \mathrm{CO}_{2} \\
5 \% \mathrm{CO}_{2}\end{array}$ & $\begin{array}{l}\overline{28} \\
28\end{array}$ & $\begin{array}{l}13 \\
17 \\
26\end{array}$ & $\begin{array}{l}0.83 \\
0.86 \\
0.73\end{array}$ & $\begin{array}{r}545 \\
830 \\
1,238\end{array}$ & $\begin{array}{l}166 \\
238 \\
374\end{array}$ & $\begin{array}{r}7.08 \\
14.11 \\
32.23\end{array}$ & $\begin{array}{r}4.92 \\
10.03 \\
22.50\end{array}$ & $\begin{array}{l}101 \\
125 \\
134\end{array}$ \\
\hline \multirow[t]{2}{*}{ H. S. } & Rest & 24 & $\mathbf{M}$ & 1.90 & & & $\begin{array}{l}\text { Rm. air } \\
3 \% \mathrm{CO}_{2} \\
5 \% \mathrm{CO}_{2}\end{array}$ & $\begin{array}{l}\overline{26} \\
26\end{array}$ & $\begin{array}{l}8.3 \\
12.3 \\
23\end{array}$ & $\begin{array}{l}0.86 \\
0.83 \\
0.75\end{array}$ & $\begin{array}{r}788 \\
951 \\
1,433\end{array}$ & $\begin{array}{l}269 \\
300 \\
745\end{array}$ & $\begin{array}{r}6.57 \\
11.72 \\
33.0\end{array}$ & $\begin{array}{r}4.33 \\
8.02 \\
15.84\end{array}$ & $\begin{array}{l}102 \\
118 \\
129\end{array}$ \\
\hline & $\begin{array}{l}\text { Post } \\
\text { ASA }\end{array}$ & & & & 1.8 & $\begin{array}{l}14.1 \\
13.0 \\
13.3\end{array}$ & $\begin{array}{l}\text { Rm. air } \\
3 \% \mathrm{CO}_{2} \\
5 \% \mathrm{CO}_{2}\end{array}$ & $\begin{array}{l}\overline{30} \\
27\end{array}$ & $\begin{array}{l}15 \\
20.5 \\
28\end{array}$ & $\begin{array}{l}0.83 \\
0.77 \\
0.92\end{array}$ & $\begin{array}{r}561 \\
665 \\
1,377\end{array}$ & $\begin{array}{l}249 \\
196 \\
393\end{array}$ & $\begin{array}{r}8.42 \\
13.63 \\
38.56\end{array}$ & $\begin{array}{r}4.68 \\
9.60 \\
27.50\end{array}$ & $\begin{array}{l}102 \\
124 \\
137\end{array}$ \\
\hline \multirow[t]{3}{*}{ G. S. } & Rest & 23 & $\mathbf{M}$ & 1.92 & & & $\begin{array}{l}\text { Rm. air } \\
3 \% \mathrm{CO}_{2} \\
5 \% \mathrm{CO}_{2}\end{array}$ & $\begin{array}{l}\overline{33} \\
26\end{array}$ & $\begin{array}{c}9 \\
11.3 \\
13\end{array}$ & $\begin{array}{l}0.75 \\
0.75 \\
0.65\end{array}$ & $\begin{array}{r}646 \\
1,024 \\
1,843\end{array}$ & $\begin{array}{l}211 \\
338 \\
935\end{array}$ & $\begin{array}{r}5.81 \\
11.61 \\
23.96\end{array}$ & $\begin{array}{r}3.92 \\
7.78 \\
11.81\end{array}$ & $\begin{array}{r}93 \\
117 \\
125\end{array}$ \\
\hline & $\begin{array}{l}\text { Post } \\
\text { ASA }\end{array}$ & & & & 1.8 & $\begin{array}{l}11.8 \\
12.8 \\
11.8\end{array}$ & $\begin{array}{l}\text { Rm. air } \\
3 \% \mathrm{CO}_{2} \\
5 \% \mathrm{CO}_{2}\end{array}$ & $\begin{array}{l}\overline{29} \\
30\end{array}$ & $\begin{array}{l}9.3 \\
12 \\
15.5\end{array}$ & $\begin{array}{l}0.81 \\
0.84 \\
0.79\end{array}$ & $\begin{array}{r}706 \\
1,098 \\
2,204\end{array}$ & $\begin{array}{l}245 \\
376 \\
914\end{array}$ & $\begin{array}{r}6.59 \\
13.17 \\
34.17\end{array}$ & $\begin{array}{r}4.30 \\
8.67 \\
20.02\end{array}$ & $\begin{array}{r}97 \\
122 \\
128\end{array}$ \\
\hline & Rest & & & & & & $\begin{array}{l}\text { Rm. air } \\
3 \% \mathrm{CO}_{2} \\
5 \% \mathrm{CO}_{2}\end{array}$ & $\begin{array}{l}\overline{28} \\
28\end{array}$ & $\begin{array}{r}7.7 \\
9.3 \\
11.3\end{array}$ & $\begin{array}{l}0.77 \\
0.70 \\
0.79\end{array}$ & $\begin{array}{r}693 \\
1,000 \\
2,070\end{array}$ & $\begin{array}{l}211 \\
218 \\
839\end{array}$ & $\begin{array}{r}5.33 \\
9.30 \\
23.42\end{array}$ & $\begin{array}{r}3.71 \\
7.27 \\
13.94\end{array}$ & $\begin{array}{r}95 \\
114 \\
127\end{array}$ \\
\hline
\end{tabular}

* Symbols used are: $f$, respiratory frequency; $R_{E}$, respiratory exchange ratio, expired air; $V_{T}$, tidal volume, ml.; $\mathrm{V}_{\mathrm{D}}$, physiological (Bohr) dead space to $\mathrm{CO}_{2}$ in ml., including both instrumental (60 ml.) and personal dead space; $\dot{\mathrm{V}}_{\mathrm{E}}$, total pulmonary ventilation, liters per minute at body temperature and pressure saturated with water vapor; $\dot{V}_{\Lambda}$, effective alveolar ventilation, liters per minute BTPS; $\mathrm{PA}_{\mathrm{O}_{2}}$, calculated mean alveolar oxygen tension, $\mathbf{m m}$. $\mathrm{Hg}$.

† Body surface area, square meters.

$\mp$ Acetyl salicylic acid.

8 For a discussion of changes observed with $\mathrm{CO}_{2}$ breathing in normal subjects, see a previous report (3). 
TABLE II

Physiologic data relative to the arterial blood at rest and following salicylate ingestion *

\begin{tabular}{|c|c|c|c|c|c|c|c|c|c|}
\hline Subject & State & $\begin{array}{c}\text { Inspired } \\
\text { gas } \\
\text { mixture }\end{array}$ & pHs & $\left(\mathrm{H}^{+}\right) \mathbf{a}$ & $\mathrm{Cs}_{\mathrm{Co}_{2}}$ & $\mathrm{~Pa}_{\mathrm{cos}_{2}} \neq$ & $\mathrm{Sa}_{\mathrm{O}_{2}}$ & Vc & $\left(B_{B}+\right) b$ \\
\hline \multirow[t]{2}{*}{ B. C. } & Rest & $\begin{array}{l}\text { Rm. air } \\
3 \% \mathrm{CO}_{2} \\
5 \% \mathrm{CO}_{2}\end{array}$ & $\begin{array}{l}7.40 \\
7.39 \\
7.36\end{array}$ & $\begin{array}{l}39.8 \\
40.7 \\
43.6\end{array}$ & $\begin{array}{l}58.7 \\
61.5 \\
62.7\end{array}$ & $\begin{array}{l}41.5 \\
44.5 \\
48.5\end{array}$ & $\begin{array}{r}97 \\
99 \\
100\end{array}$ & $\begin{array}{l}41 \\
41 \\
41\end{array}$ & $\begin{array}{l}47.5 \\
49 \\
49\end{array}$ \\
\hline & $\begin{array}{l}\text { Post } \\
\text { ASA }\end{array}$ & $\begin{array}{l}\text { Rm. air } \\
3 \% \mathrm{CO}_{2} \\
5 \% \mathrm{CO}_{2}\end{array}$ & $\begin{array}{l}7.41 \\
7.41 \\
7.39\end{array}$ & $\begin{array}{l}38.9 \\
38.9 \\
40.7\end{array}$ & $\begin{array}{l}58.3 \\
59 \\
61.5\end{array}$ & $\begin{array}{l}40 \\
40.5 \\
44\end{array}$ & $\begin{array}{r}95 \\
98 \\
100\end{array}$ & $\begin{array}{l}40 \\
41 \\
42\end{array}$ & $\begin{array}{l}48 \\
48 \\
48.5\end{array}$ \\
\hline \multirow[t]{2}{*}{ H. S. } & Rest & $\begin{array}{l}\text { Rm. air } \\
3 \% \mathrm{CO}_{2} \\
5 \% \mathrm{CO}_{2}\end{array}$ & $\begin{array}{l}7.40 \\
7.39 \\
7.36\end{array}$ & $\begin{array}{l}39.8 \\
40.7 \\
43.6\end{array}$ & $\begin{array}{l}58.7 \\
60 \\
62.4\end{array}$ & $\begin{array}{l}41.5 \\
43.5 \\
48\end{array}$ & $\begin{array}{l}95 \\
95 \\
97\end{array}$ & $\begin{array}{l}45 \\
46 \\
46\end{array}$ & $\begin{array}{l}48 \\
49 \\
48.5\end{array}$ \\
\hline & $\begin{array}{l}\text { Post } \\
\text { ASA }\end{array}$ & $\begin{array}{l}\text { Rm. air } \\
3 \% \mathrm{CO}_{2} \\
5 \% \mathrm{CO}_{2}\end{array}$ & $\begin{array}{l}7.42 \\
7.42 \\
7.40\end{array}$ & $\begin{array}{l}38.0 \\
38.0 \\
39.8\end{array}$ & $\begin{array}{l}59.9 \\
60.6 \\
62\end{array}$ & $\begin{array}{l}40 \\
41 \\
44\end{array}$ & $\begin{array}{r}97 \\
99 \\
100\end{array}$ & $\begin{array}{l}47 \\
47 \\
47\end{array}$ & $\begin{array}{l}50 \\
50.5 \\
50\end{array}$ \\
\hline \multirow[t]{3}{*}{ G. S. } & Rest & $\begin{array}{l}\text { Rm. air } \\
3 \% \mathrm{CO}_{2} \\
5 \% \mathrm{CO}_{2}\end{array}$ & $\begin{array}{l}7.40 \\
7.38 \\
7.34\end{array}$ & $\begin{array}{l}39.8 \\
41.7 \\
45.7\end{array}$ & $\begin{array}{l}63.1 \\
61.8 \\
63\end{array}$ & $\begin{array}{l}44.5 \\
46 \\
51\end{array}$ & $\begin{array}{r}98 \\
97 \\
100\end{array}$ & $\begin{array}{l}47 \\
46 \\
47\end{array}$ & $\begin{array}{l}50 \\
50 \\
49\end{array}$ \\
\hline & $\begin{array}{l}\text { Post } \\
\text { ASA }\end{array}$ & $\begin{array}{l}\text { Rm. air } \\
3 \% \mathrm{CO}_{2} \\
5 \% \mathrm{CO}_{2}\end{array}$ & $\begin{array}{l}7.40 \\
7.38 \\
7.35\end{array}$ & $\begin{array}{l}39.8 \\
41.7 \\
44.6\end{array}$ & $\begin{array}{l}61.8 \\
61.1 \\
60.8\end{array}$ & $\begin{array}{l}44 \\
45 \\
48\end{array}$ & $\begin{array}{r}100 \\
99 \\
98\end{array}$ & $\begin{array}{l}45 \\
47 \\
48\end{array}$ & $\begin{array}{l}50 \\
49 \\
49\end{array}$ \\
\hline & Rest & $\begin{array}{l}\text { Rm. air } \\
3 \% \mathrm{CO}_{2} \\
5 \% \mathrm{CO}_{2}\end{array}$ & $\begin{array}{l}7.40 \\
7.39 \\
7.36\end{array}$ & $\begin{array}{l}39.8 \\
40.7 \\
43.7\end{array}$ & $\begin{array}{l}60.4 \\
61.2 \\
61.5\end{array}$ & $\begin{array}{l}42.5 \\
44.5 \\
48\end{array}$ & $\begin{array}{l}96 \\
97 \\
99\end{array}$ & $\begin{array}{l}48 \\
48 \\
49\end{array}$ & $\begin{array}{l}49 \\
50 \\
50\end{array}$ \\
\hline
\end{tabular}

* Symbols used are: $\mathrm{pHs}$, serum $\mathrm{pH} ;\left(\mathrm{H}^{+}\right) \mathrm{a}$, hydrogen ion concentration, billionths of moles per liter; $\mathrm{Cs}_{\mathrm{CO}_{2} \text {, serum }}$ $\mathrm{CO}_{2}$ content, vol. per cent; $\mathrm{Pa}_{\mathrm{CO}_{2}}, \mathrm{CO}_{2}$ tension, $\mathrm{mm}$. $\mathrm{Hg} ; \mathrm{Sa}_{\mathrm{O}_{2}}$, oxygen saturation; $\mathrm{V}_{\mathrm{c}}$, hematocrit; $\left(\mathrm{B}_{\mathrm{B}}{ }^{+}\right) \mathrm{b}$, calculated whole blood buffer base, $\mathrm{mEq} . / \mathrm{L}$.

$\dagger$ Acetyl salicylic acid.

$\ddagger$ In calculating $\mathrm{Pa}_{\mathrm{CO}_{2}}$ from the Henderson-Hasselbalch relationship, $\mathrm{pK}$ ' for carbonic acid in blood serum was taken as 6:10, and the solubility coefficient of $\mathrm{CO}_{2}$ in serum as 0.510 at $38^{\circ}$ centigrade.

After salicylate ingestion there was little change in the values obtained at rest relative either to pulmonary ventilation or to arterial blood. Particular attention is called to the alveolar ventilation and arterial $\mathrm{CO}_{2}$ tension in this regard (Tables I, II). The constancy of arterial blood buffer base values both before and after salicylate is taken as evidence that little renal compensation occurred during the period of respiratory acidosis induced by $\mathrm{CO}_{2}$. With $\mathrm{CO}_{2}$ inhalation, the relation between effective alveolar ventilation and arterial $\mathrm{CO}_{2}$ tension or hydrogen ion concentration was essentially linear both before and after salicylate ingestion. As indicated by the slopes of the stimulus response curves, an increased sensitivity to the chemical stimulus in terms of either arterial $\mathrm{CO}_{2}$ tension or hydrogen ion concentration was found in all subjects following salicylate

\begin{tabular}{|c|c|c|c|c|}
\hline & Subject & Control & $\begin{array}{c}\text { After } \\
\text { salicylate }\end{array}$ & $\begin{array}{l}\text { Percentage } \\
\text { increase in } \\
\text { sensitivity }\end{array}$ \\
\hline $\begin{array}{l}\text { Increase in effective alveolar ventilation, liters per minute } \\
\text { BTPS, associated with a rise of } 1 \mathrm{~mm} \text {. } \mathrm{Hg} \text { in arterial } \mathrm{CO}_{2} \\
\text { tension. }\end{array}$ & $\begin{array}{l}\text { B. C. } \\
\text { H.S. } \\
\text { G.S. }\end{array}$ & $\begin{array}{l}1.37 \\
1.75 \\
1.44\end{array}$ & $\begin{array}{l}4.0 \\
5.75 \\
3.88\end{array}$ & $\begin{array}{l}192 \\
228 \\
170\end{array}$ \\
\hline $\begin{array}{l}\text { Increase in effective alveolar ventilation, liters per min. } \\
\text { BTPS, associated with a rise in arterial hydrogen ion } \\
\text { concentration of } 1 \text { billionth of a mole per liter. }\end{array}$ & $\begin{array}{l}\text { B. C. } \\
\text { H.S. } \\
\text { G. S.* }\end{array}$ & $\begin{array}{l}2.2 \\
2.8 \\
1.9\end{array}$ & $\begin{array}{r}8.2 \\
11.4 \\
3.5\end{array}$ & $\begin{array}{r}272 \\
307 \\
84\end{array}$ \\
\hline
\end{tabular}

\footnotetext{
* Control values represent average of two studies.
} 


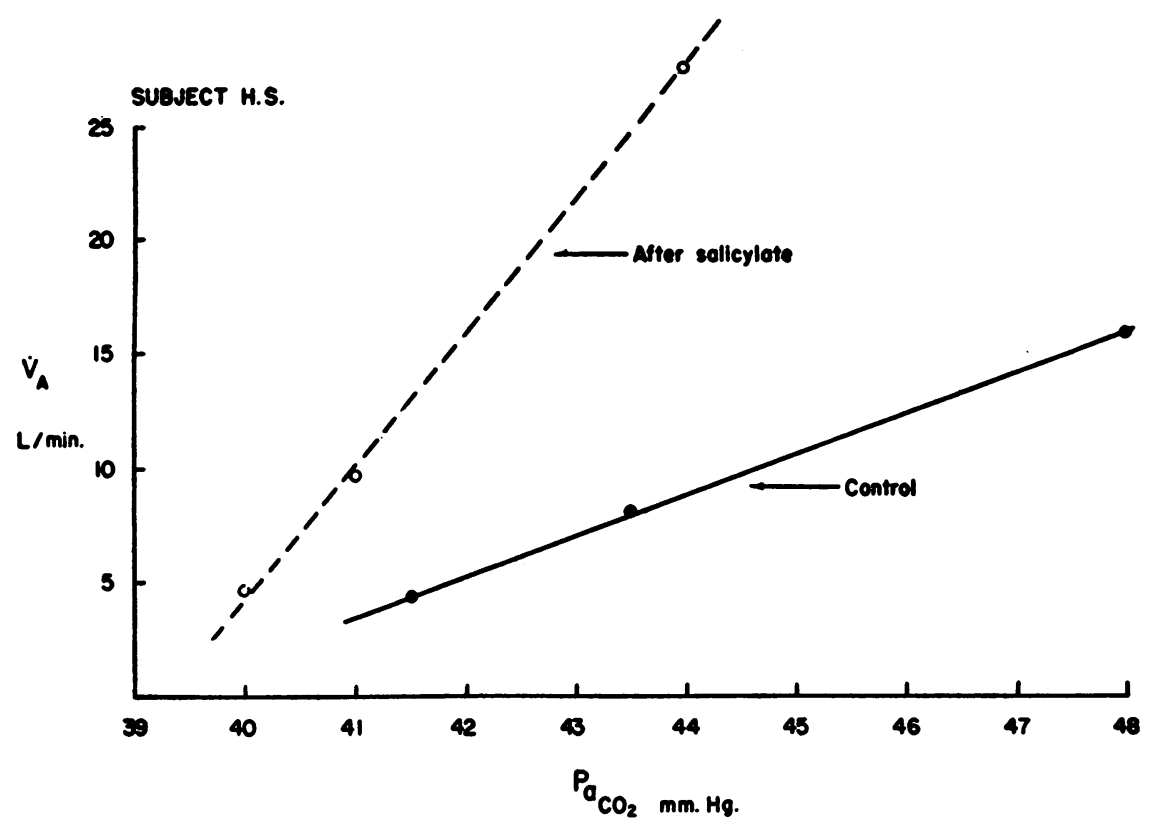

Fig. 1. Response to the $\mathrm{CO}_{2}$ Stmulus Before and After Salicylate Ingestion

Effective alveolar ventilation in liters per minute (BTPS) on the ordinate is plotted against arterial $\mathrm{CO}_{2}$ tension in $\mathrm{mm}$. $\mathrm{Hg}$ on the abscissa to obtain the slopes of the stimulus-response or sensitivity curves.

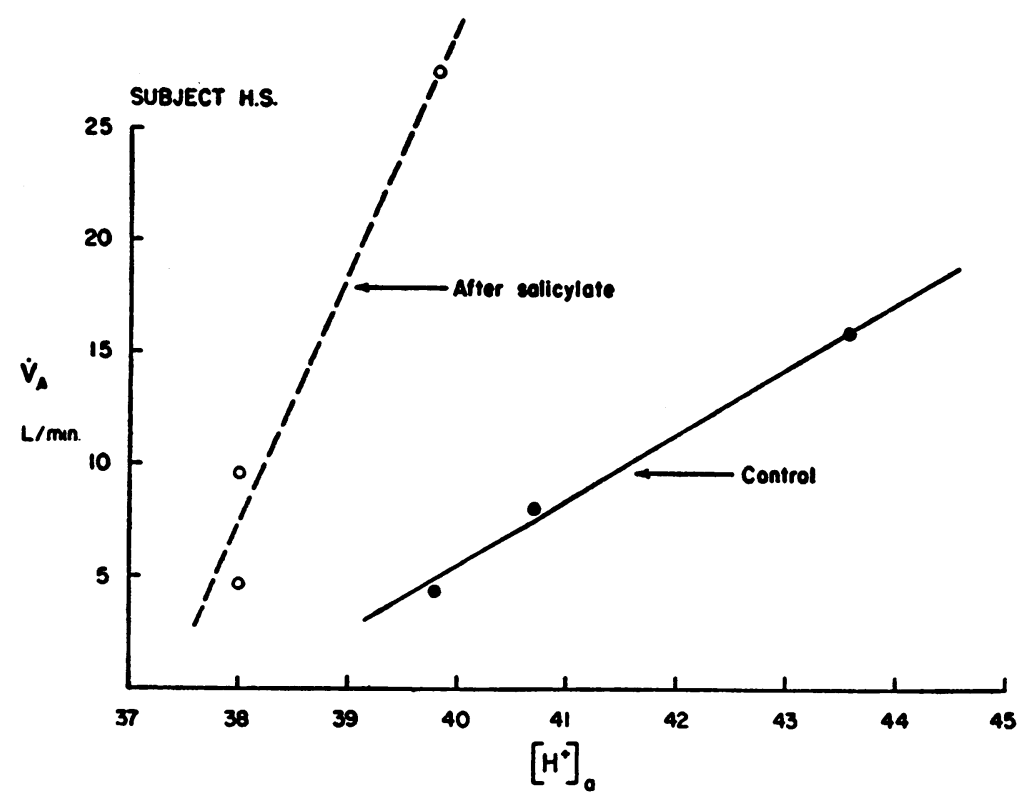

Fig. 2. Response to the Hydrogen Ion Sttmulus Before and Atter Salicylate Ingestion

With arterial hydrogen ion concentration in billionths of moles per liter (see Table II) on the abscissa, sensitivity curves are constructed as indicated in Figure 1. 
ingestion. The stimulus response curves of subject $H$. S. are shown in Figures 1 and 2. In Table III are shown the increments in effective alveolar ventilation associated with unit rise in arterial $\mathrm{CO}_{2}$ tension and hydrogen ion concentration during the control observations and after salicylate, together with the percentage increase in sensitivity induced by salicylate in each subject. Even at the relatively low blood salicylate levels obtained, increases in sensitivity ranging from 84 per cent to 307 per cent occurred.

\section{DISCUSSION}

Possible mechanisms which have been suggested (9) to account for salicyl hyperpnea are (a) a direct stimulating effect upon the respiratory center, (b) a metabolic acidosis resulting from fixed acid degradation products of these compounds. In regard to the latter, recently reported studies by Singer (10) indicate that there may be accumulation of an as yet unidentified fixed acid in the blood with metabolic acidosis in the advanced phase of salicylate poisoning. However, it seems well established that the hyperpnea accompanying large therapeutic dosage or mild to moderate toxicity is associated with an uncomplicated respiratory alkalosis $(9,10)$.

The results of this study are interpreted as providing direct experimental evidence that an increase in the sensitivity of the nervous regulatory mechanism to normal chemical stimuli is at least one means whereby hyperventilation is induced by salicylates.

\section{SUMMARY AND CONCLUSIONS}

1. The sensitivity of the respiratory nervous regulatory mechanism to the $\mathrm{CO}_{2}$ inhalation stimulus was determined in three normal subjects before and after salicylate ingestion, relating ef- fective alveolar ventilation to arterial $\mathrm{CO}_{2}$ tension and hydrogen ion concentration.

2. With blood salicylate levels of the order 12 to $16 \mathrm{mg}$. per cent, respiratory sensitivity to the carbon dioxide-hydrogen ion stimulus increased 84 to 307 per cent.

3. It is suggested that this increased sensitivity to a normal chemical stimulus is one mechanism whereby salicylates induce hyperventilation.

\section{REFERENCES}

1. Haldane, J. S., and Priestley, J. G., The regulation of the lung-ventilation. J. Physiol., 1905, 32, 225.

2. Gray, J. S., Pulmonary Ventilation and Its Physiological Regulation. Springfield, Ill., Charles C Thomas, 1950.

3. Alexander, J. K., West, J. R., Wood, J. A., and Richards, D. W., Analysis of the respiratory response to carbon dioxide inhalation in varying clinical states of hypercapnia, anoxia, and acidbase derangement. J. Clin. Invest., 1955, 34, 511.

4. Nielsen, M., Untersuchungen über die Atemregulation beim Menschen, besundersmit Hinblick auf die Art des chemischen Reizes. Skandinav. Arch. f. Physiol., Supp. 10, 87, 1936.

5. Hastings, A. B., and Sendroy, J., Jr., Studies of acidosis. XX. The colorimetric determination of blood $\mathrm{pH}$ at body temperature without buffer standards. J. Biol. Chem., 1924, 61, 695.

6. Smith, P. K., Gleason, H. L., Stoll, C. G., and Ogorzalek, S., Studies on the pharmacology of salicylates. J. Pharmacol. \& Exper. Therap., 1946, 87, 237.

7. Standardization of definitions and symbols in respiratory physiology. Federation Proc., 1950, 9, 602.

8. Singer, R. B., and Hastings, A. B., An improved clinical method for the estimation of disturbances of the acid-base balance of human blood. Medicine, 1948, 27, 223.

9. Gross, M., and Greenberg, L. A., The Salicylates: A Critical Bibliographic Review. New Haven, Hillhouse Press, 1948.

10. Singer, R. B., The acid-base disturbance in salicylate intoxication. Medicine, 1954, 33, 1.

\section{SPECIAL NOTICE TO SUBSCRIBERS}

Post Offices will no longer forward the Journal when you move.

Please notify The Journal of Clinical Investigation, Business Office, 622 West 168th Street, New York 32, N. Y. at once when you have a change of address, and do not omit the zone number if there is one. 